\title{
MicroRNA-210 is upregulated by hypoxia-inducible factor-1 $\alpha$ in the stromal cells of giant cell tumors of bone
}

\author{
SHIBING GUO $^{1 *}$, RUI BAI ${ }^{1 *}$, WANLIN LIU ${ }^{1}$, AIQING ZHAO $^{2}$, ZHENQUN ZHAO $^{1}$, \\ YUXIN WANG $^{1}$, YONG WANG ${ }^{1}$, WEI ZHAO ${ }^{1}$ and WENXUAN WANG ${ }^{1}$ \\ ${ }^{1}$ Department of Orthopedics, Second Affiliated Hospital of Inner Mongolia Medical University, Hohhot, \\ Inner Mongolia 010050; ${ }^{2}$ Department of Radiology, First Affiliated Hospital of Inner Mongolia Medical University, \\ Hohhot, Inner Mongolia 010059, P.R. China
}

Received July 6, 2014; Accepted March 20, 2015

DOI: $10.3892 / \mathrm{mmr} .2015 .4170$

\begin{abstract}
To date, little is known regarding the molecular mechanisms underlying the deregulation of the giant cell tumor of bone (GCTB). Hypoxia has been confirmed to be a characteristic observed in a variety of types of cancer, and a pivotal role for hypoxia-inducible factor- $1 \alpha(\mathrm{HIF}-1 \alpha)$ has previously been indicated in the hypoxia adaptation of GCTBs. However, another key regulator, microRNA (miR)-210, which is closely correlated with HIF- $1 \alpha$, has not previously been identified in GCTBs. The present study therefore selected miR-210, the most significantly upregulated miRNA in hypoxic subtypes of cancer, for investigation in GCTB tissues. Reverse transcription-quantitative polymerase chain reaction was used to evaluate miR-210 expression levels in GCTB tissues and primary GCTB stromal cells. It was revealed that miR-210 and HIF-1 $\alpha$ were upregulated in GCTB specimens and in primary GCTB stromal cells under hypoxia, and a positive correlation was identified between the two molecules. Furthermore, the promotion of miR-210 expression in primary GCTB stromal cells by hypoxia was HIF-1 $\alpha$-dependent. To the best of our knowledge, the present study was the first to identify the overexpression of miR-210 in an HIF-1 $\alpha$-dependent manner in GCTB specimens, suggesting an adaptive response to hypoxia in GCTB.
\end{abstract}

Correspondence to: Professor Wanlin Liu, Department of Orthopedics, Second Affiliated Hospital of Inner Mongolia Medical University, 1 Yingfang Road, Hohhot, Inner Mongolia 010050, P.R. China

E-mail: wanlin_liunmg@163.com

Dr Aiqing Zhao, Department of Radiology, First Affiliated Hospital of Inner Mongolia Medical University, 1 Tongdaobeijie, Hohhot, Inner Mongolia 010059, P.R. China

E-mail: aiqing_zhao@163.com

${ }^{*}$ Contributed equally

Key words: hypoxia-inducible factor-1 $\alpha$, giant cell tumors of bone, microRNA-210, stromal cells

\section{Introduction}

Giant cell tumor of bone (GCTB) is a relatively uncommon, aggressive, non-cancerous type of tumor, characterized by the presence of multinucleated giant (osteoclast-like) cells. GCTB generally occurs in adults between the ages of 20 and 40 years, and occurs in males and females with equal frequency $(1,2)$. The majority of GCTBs arise in the metaphyseal-epiphyseal areas of the distal femur, proximal tibia and distal radius $(3,4)$. Despite being classified as benign, GCTBs are aggressive and up to $50 \%$ of cases are associated with local recurrence. Furthermore, up to 5\% of GCTBs metastasize to the lungs and GCTB undergoes spontaneous transformation into high-grade malignancy in $1-3 \%$ of patients $(2,5)$. However, the pathogenesis and histogenesis of GCTBs have remained elusive, without predictable histological values for evaluating the clinical outcome.

Hypoxia has been confirmed to be associated with a variety of types of cancer, and has become one of the key issues in the study of tumor physiology $(6,7)$. A group of transcription factors has been reported to be involved in the regulation of genes responsible for the metabolic changes induced under hypoxic conditions $(8,9)$. A pivotal component of this group is hypoxia-inducible factor 1 (HIF-1), which exists as a heterologous dimer, comprised of an oxygen sensitive HIF-1 $\alpha$ subunit and a constitutively expressed HIF-1 $\beta$ subunit (10). HIF-1 binds to a conserved DNA consensus sequence on the promoters of its target genes, known as hypoxia-responsive elements (11-13). Upregulation of HIF promotes the expression of gene products required for hypoxic adaptation (14), and regulates vascular endothelial growth factor (VEGF) and additional angiogenic factors $(15,16)$, which have key roles in the growth and progression of solid tumors (17-20). As a result of the generally insidious onset of symptoms in patients with GCTB, the tumors frequently grow to a large size prior to diagnosis, and therefore potentially undergo hypoxia as the overgrowth of tumor cells distances them from the local microvessels (21). Few studies have previously indicated the significant role of HIF in hypoxia adaptation in GCTBs; however, Knowles et al (21) revealed that HIF is promoted in GCTBs and mediates paracrine effects on monocyte-osteoclast differentiation via the induction of VEGF. 
The neoplastic 'driver' role of the stromal cell was indicated by Knowles et al (21) and the results of additional studies (22). The in vitro experiments by Knowles et al (21) indicated that HIF was induced in primary GCTB stromal cells following hypoxia. It was also demonstrated that the accumulation of giant cells is due, in part, to the high levels of receptor activator of nuclear factor- $\kappa \mathrm{B}$ ligand expression by the neoplastic stromal cells (23-25), suggesting a significant role for the stromal cell. Treatment of GCTB stromal cells with parathyroid hormone-related protein significantly increased the number of multinucleated cells formed from RAW 264.7 cells in co-culture experiments (26). Interleukin-17A has also been shown to be overexpressed in GCTB stromal cells, and to stimulate the progression of GCTBs (27). Additionally, it was demonstrated that stromal cells in GCTB expressed matrix metalloproteinase-9 $(28,29)$ and several types of bone morphogenetic protein (BMP-2, 3, 4, 5 and 6) (30).

MicroRNAs (miRNAs) are 18-22 nucleotide non-coding RNA molecules that regulate gene expression in a variety of organisms, ranging from nematodes to humans (31), and are involved in a broad array of mammalian cellular processes (32-34). The suppression of target genes by miRNAs induce diverse biological outcomes during normal development and pathological responses. In particular, alterations in miRNA expression have marked effects on the progression of tumorigenesis (35-37). Studies have indicated the oncogenic or tumor suppressive roles of certain deregulated miRNAs in bone tumors, particularly in osteosarcoma (38-43). miR-210 is a key regulator of the hypoxic response, and its upregulation has been observed in all cell types evaluated under hypoxic conditions so far (44). In addition, miR-210 was found to be a positive regulator of osteoblastic differentiation via inhibition of activin A receptor type 1B (45). However, to the best of our knowledge there has been no previous report regarding miR-210, the characteristic miRNA deregulated under hypoxia, in GCTBs.

In the present study, the expression of miR-210 and HIF-1 $\alpha$ was quantitatively determined in 42 GCTB specimens by reverse transcription-quantitative polymerase chain reaction (RT-qPCR) and western blot analyses. The induction of miR-210 and HIF-1 $\alpha$ expression in primary stromal cells isolated from GCTB tissues under hypoxic conditions was also further confirmed. Subsequently, the regulatory role of HIF-1 $\alpha$ on miR-210 expression in primary stromal cells was evaluated. The present study aimed to provide novel information regarding the mechanisms underlying GCTB tumorigenesis.

\section{Materials and methods}

Tissue specimens and ethical approval. The utilization of 42 sacral GCTB specimens was approved by the Internal Review Board of the Second Affiliated Hospital of Inner Mongolia Medical University (Hohhot, China). All 42 specimens were obtained from surgical resections from sacral GCTB patients registered at the aforementioned hospital, between January 2008 and December 2011. A total of 11 osteochondroma tissues were obtained from patients matched for age, gender, and tumor location for use as control specimens. All tissue samples for miR-210 and HIF-1 $\alpha$ expression analysis were frozen at $-80^{\circ} \mathrm{C}$ immediately following surgical resection. The GCTB tissue for primary stromal cell isolation was obtained from a GCT located on the distal femur and permission was given by the patient who was registered at the Second Affiliated Hospital of Inner Mongolia Medical University in September 2013. The GCT tissue was put on ice and treated for cell isolation immediately following surgical resection. The GCTB patients selected for this study were all treated with identical programs. Prior to the operation, patients granted consent for the use of the excised cancer tissue in medical or scientific research.

Isolation, culture and treatment of primary GCTB stromal cells or U2 osteosarcoma (OS) cells. Primary GCTB stromal cells were isolated from the GCT tissue from the distal femur according to a previously published protocol $(46,47)$. Briefly, the fresh tissue specimens were placed in ice-cold isolation solution (Miltenyi Biotec, Inc., San Diego, CA, USA), and homogenized. The stromal cells were isolated and basal CD146 expression was enriched with anti-CD146 monoclonal antibody-coupled magnetic beads, following the removal of CD14- and CD45-positive cells (46). The stromal cells were cultured with RPMI-1640 (Gibco Life Technologies, Carlsbad, CA, USA) supplemented with $10 \%$ fetal bovine serum (FBS) (Invitrogen Life Technologies, Carlsbad, CA, USA), antibiotics (100 mg/ml streptomycin and $100 \mathrm{U} / \mathrm{ml}$ penicillin; North China Pharmaceutical Co., Ltd, Shijiazhuang, China) and $10 \mathrm{nmol} / \mathrm{l}$ dihydrotestosterone (Sigma-Aldrich, St. Louis, MO, USA). The cells under normoxia were incubated at $37^{\circ} \mathrm{C}$, with $5 \% \mathrm{CO}_{2}$. The U2 OS cells were obtained from the Cell Resource Center of Chinese Academy of Medical Sciences (Beijing, China), and cultured in Eagle's minimum essential medium or McCoy's 5a modified medium supplemented with $10 \% \mathrm{FBS}$, and were incubated at $37^{\circ} \mathrm{C}$ with $5 \% \mathrm{CO}_{2}$. For hypoxia treatment, cells were placed in a hypoxia incubator (HERAcell 150i $\mathrm{CO}_{2}$ incubator; Thermo Fisher Scientific, Inc., Waltham, MA, USA) infused with $5 \% \mathrm{CO}_{2}, 3 \% \mathrm{O}_{2}$ and $\mathrm{N}$. Small interference (si) HIF-1 $\alpha$ and siRNA control oligomers were synthesized by GenePharma Technology (Shanghai, China) and were transfected into the stromal cells at a concentration of $5 \mathrm{nM}$ with Lipofectamine $^{\circledR} 2000$ (Invitrogen Life Technologies) to suppress HIF-1 $\alpha$ expression. The overexpression of HIF-1 $\alpha$ was induced with HIF-1 $\alpha$-pcDNA3.1 plasmid (Sino Biological, Inc., Beijing, China) transfection (48).

RNA extraction and $R T-q P C R$. A mirVana miRNA Isolation kit (Ambion, Austin, TX, USA) was used to extract miRNA from clinical specimens or cultured cells. The mirVana qRT-PCR miRNA Detection kit (Ambion) was used to quantify miR-210 expression, and U6 small nuclear RNA was used as an internal control. The $\Delta \Delta \mathrm{Ct}$ method was used to calculate the relative quantification (49). The RNeasy Mini kit (Qiagen, Valencia, CA, USA) was used to extract total messenger (m)RNA from clinical specimens or cell samples, and RT-qPCR analysis of Drosha, Dicer and HIF-1 $\alpha$ mRNA expression was performed using SYBR Green RT-PCR kit (Takara Bio, Inc., Tokyo, Japan) with the LightCycler 2.0 (Roche Diagnostics $\mathrm{GmbH}$, Mannheim, Germany). The qPCR was performed as follows: $42^{\circ} \mathrm{C}$ for $5 \mathrm{~min}, 95^{\circ} \mathrm{C}$ for $10 \mathrm{sec}$, followed by 40 cycles at $95^{\circ} \mathrm{C}$ for $15 \mathrm{sec}$ and $60^{\circ} \mathrm{C}$ for $30 \mathrm{sec}$. All mRNA expression levels were normalized to GAPDH and quantified using the $\Delta \Delta \mathrm{Ct}$ method (49). 
Table I. Correlation between miR-210 and HIF-1 $\alpha$ expression levels and clinicopathological parameters in giant cell tumor of bone specimens.

\begin{tabular}{|c|c|c|c|c|c|}
\hline \multirow{2}{*}{$\begin{array}{l}\text { Clinicopathological } \\
\text { parameter }\end{array}$} & \multirow[b]{2}{*}{ Cases (n) } & \multicolumn{2}{|c|}{ miR-210 levels } & \multicolumn{2}{|c|}{ HIF- $1 \alpha$ mRNA levels } \\
\hline & & Mean \pm SD & P-value & Mean \pm SD & P-value \\
\hline Gender & & & 0.365 & & 0.640 \\
\hline Male & 20 & $2.985 \pm 0.547$ & & $3.136 \pm 0.703$ & \\
\hline Female & 22 & $3.214 \pm 0.623$ & & $3.076 \pm 0.672$ & \\
\hline Age (years) & & & 0.134 & & 0.093 \\
\hline$\leq 20$ & 12 & $3.327 \pm 0.606$ & & $3.323 \pm 0.574$ & \\
\hline $21-40$ & 23 & $2.926 \pm 0.502$ & & $3.042 \pm 0.620$ & \\
\hline$>41$ & 7 & $3.312 \pm 0.622$ & & $2.937 \pm 0.663$ & \\
\hline Jaffe grade & & & $0.031^{\mathrm{a}}$ & & $0.022^{\mathrm{a}}$ \\
\hline I & 14 & $2.468 \pm 0.381$ & & $2.994 \pm 0.525$ & \\
\hline II & 23 & $3.336 \pm 0.533$ & & $3.102 \pm 0.578$ & \\
\hline III & 5 & $3.826 \pm 0.420$ & & $3.431 \pm 0.626$ & \\
\hline Recurrence & & & $0.004^{\mathrm{b}}$ & & $0.009^{\mathrm{b}}$ \\
\hline No & 33 & $2.915 \pm 0.436$ & & $2.968 \pm 0.564$ & \\
\hline Yes & 9 & $3.802 \pm 0.562$ & & $3.608 \pm 0.731$ & \\
\hline
\end{tabular}

${ }^{\mathrm{a}} \mathrm{P}<0.05,{ }^{\mathrm{b}} \mathrm{P}<0.01$, compared with the three groups. miR-210, microRNA-210; HIF-1 $\alpha$, hypoxia-inducible factor-1 $\alpha$; mRNA, messenger RNA; $\mathrm{SD}$, standard deviation.

Western blot analysis. Tissue samples for immunoblotting were placed in ice-cold isolation solution and homogenized. Following homogenization, total protein concentration was measured using the bicinchoninic acid assay protein assay reagent kit (Thermo Fisher Scientific, Inc.) and was adjusted to $2 \mathrm{mg} / \mathrm{ml}$ with isolation solution. Equal quantities of protein and sample buffer were separated by $12 \%$ SDS-PAGE, and subsequently transferred onto a polyvinylidene difluoride membrane. The membrane was blocked with Tris-buffered saline containing $5 \%$ milk at $4^{\circ} \mathrm{C}$ for $3 \mathrm{~h}$, and incubated with Dicer (cat. no. sc-30226), Drosha (cat. no. sc-33778), HIF-1 $\alpha$ (cat. no. sc-10790) or GAPDH (cat. no. sc-25778) rabbit polyclonal antibodies (1:500; Santa Cruz Biotechnology, Inc., Dallas, TX, USA), followed by incubation with horseradish peroxidase-conjugated mouse anti-rabbit secondary antibody (1:1,000; Cell Signaling Technology, Inc., Danvers, MA, USA). The proteins were detected using enhanced chemiluminescence (Thermo Fisher Scientific, Inc.). All immunoblots are representative of at least three independent experiments.

Statistical analysis. Statistical analyses were performed using SPSS 16.0 software (SPSS, Inc., Chicago, IL, USA). The differences in Dicer, Drosha and HIF-1 $\alpha$ expression between the two groups were analyzed by Student's t-test. Correlations between miR-210 and HIF-1 $\alpha$ expression were analyzed using the Spearman's rank correlation coefficient. $\mathrm{P}<0.05$ was considered to indicate a statistically significant difference.

\section{Results}

miR-210 is upregulated in GCTB specimens. miR-210, the most significantly upregulated miRNA in cancer under hypoxic conditions, was selected for investigation in GCTB tissues in the present study. RT-qPCR was used to evaluate miR-210 expression levels in 42 GCTB tissues and 11 osteochondroma tissues. The clinical information regarding the patients with GCTB evaluated in the present study is listed in Table I. The results demonstrated that the relative miR-210 expression levels in GCTB were 3.105 \pm 1.002 , significantly higher than those in the osteochondroma tissues $(1.010 \pm 0.194)$ $(\mathrm{P}<0.01$; Fig. 1A). In order to confirm the overexpression of miR-210, the miR-210 protein expression levels in the above specimens were also assessed by western blotting. The results of the western blot analysis also demonstrated significantly higher expression of miR-210 in GCTB specimens than those in the osteochondroma specimens $(35.939 \pm 9.033$ vs. 22.791 \pm 4.217$)(\mathrm{P}<0.05$; Fig. 1B). It was therefore concluded that miR-210 was upregulated in GCTB specimens. To further evaluate the upregulation of miR-210 in GCTBs, the expression of key miRNA-processing enzymes, Dicer and Drosha, was evaluated in the GCTB specimens. The results of western blotting (Fig. 1C and D) and RT-qPCR (Fig. 1E) analyses demonstrated that the protein and mRNA expression levels of Dicer and Drosha were upregulated in GCTB specimens. The association between miR-210 expression and clinicopathological parameters was statistically evaluated, and a significant difference in miR-210 level was detected amongst patients with varying Jaffe grades, as well as patients with or without recurrence $(\mathrm{P}=0.031$ and 0.004 , respectively). There was no significant association detected between miR-210 expression and the other clinicopathological parameters evaluated.

HIF-1 $\alpha$ is upregulated in GCTB specimens and positively correlated with miR-210 overexpression. miR-210 has 
A

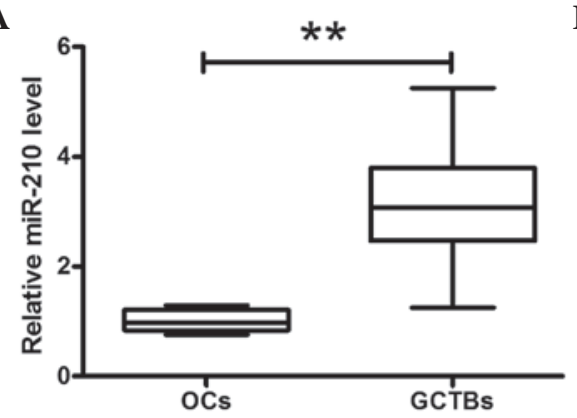

C

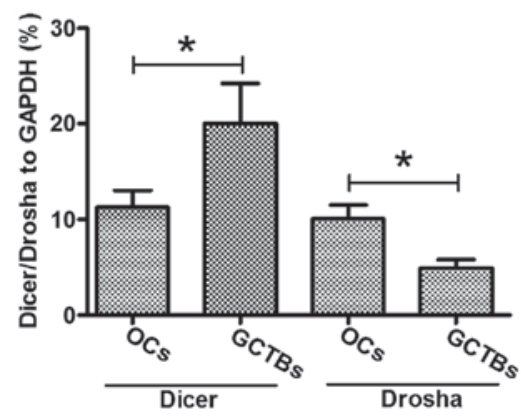

B

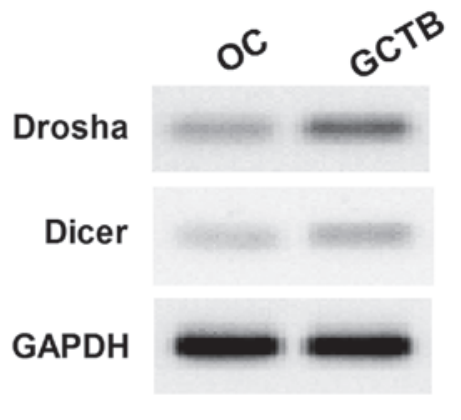

D

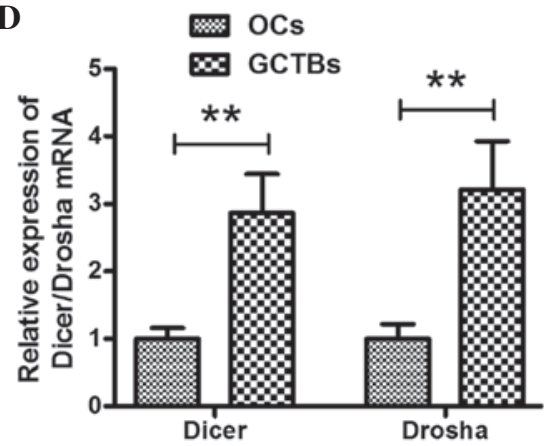

Figure 1. miR-210 and microRNA processing enzymes are upregulated in GCTB specimens. (A) Relative miR-210 expression, examined by RT-qPCR, in OC tissues $(n=11)$ and GCTB specimens $(n=42)$. Relative expression levels of Drosha and Dicer, determined by (B and C) western blot analysis and (D) RT-qPCR in OC tissues $(n=11)$ or GCTB specimens $(n=42)$. GAPDH was used as a loading control. Values are expressed as the mean \pm standard deviation; ${ }^{*} \mathrm{P}<0.05,{ }^{* *} \mathrm{P}<0.01$. miR-210; microRNA-210; GCTB, giant cell tumor of bone; RT-qPCR, reverse transcription-quantitative polymerase chain reaction; OC, osteochondroma.

A

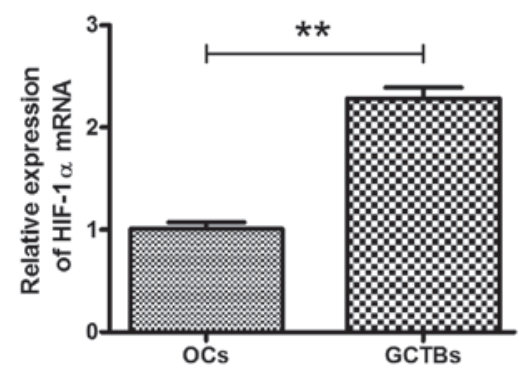

B

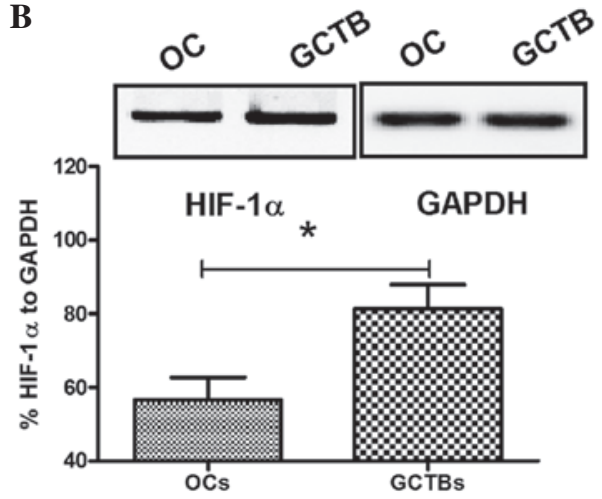

C

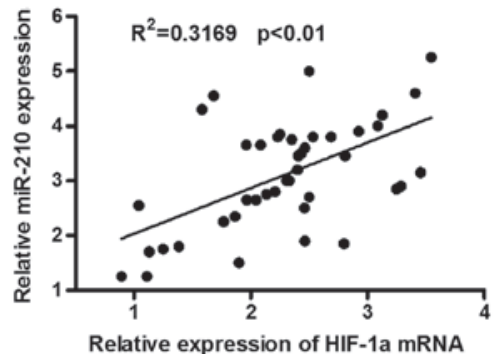

Figure 2. Positive correlation between miR-210 upregulation and HIF-1 $\alpha$ overexpression in GCTB specimens. (A) Relative HIF-1 $\alpha$ mRNA expression, examined by RT-qPCR, in OC tissues ( $\mathrm{n}=11)$ and GCTB speciments $(\mathrm{n}=42)$. (B) HIF-1 $\alpha$ protein expression in GCTB specimens $(\mathrm{n}=42)$ determined by western blot analysis. (C) Correlation between relative miR-210 and HIF-1 $\alpha$ mRNA expression. Values are expressed as the mean \pm standard deviation; ${ }^{*} \mathrm{P}<0.05,{ }^{* *} \mathrm{P}<0.01$. GCTB, giant cell tumor of bone; OC, osteochondroma; miR-210, microRNA-210; mRNA, messenger RNA; HIF-1 $\alpha$, hypoxia-inducible factor-1 $\alpha$.

previously been determined to be induced by hypoxia via HIF-1 $\alpha(50,51)$. To evaluate the hypoxic regulation of miR-210 in GCTB specimens, HIF-1 $\alpha$ mRNA expression in the GCTB and osteochondroma specimens was determined by RT-qPCR. As shown in Fig. 2A, the relative HIF-1 $\alpha$ mRNA expression was $2.286 \pm 0.677$ in the GCTB specimens, significantly higher than $1.010 \pm 0.194$ in the osteochondroma specimens $(\mathrm{P}<0.01)$. HIF-1 $\alpha$ overexpression was also evaluated in the aforementioned specimens by western blotting, and the HIF- $1 \alpha$ protein expression relative to GAPDH was $81.333 \pm 11.590 \%$, also significantly higher than $56.667 \pm 10.599 \%$ in the osteochondroma specimens $(\mathrm{P}<0.05$; Fig. 2B). To further examine the correlation between miR-210 overexpression and HIF-1 $\alpha$ upregulation, Spearman's rank analysis was conducted on the miR-210 and HIF- $1 \alpha$ mRNA expression levels in each GCTB specimen. It was revealed that the HIF-1 $\alpha$ mRNA expression was positively correlated with miR-210 expression in GCTB specimens. $\left(\mathrm{R}^{2}=0.3169\right.$, $\mathrm{P}<0.01$; Fig. 2C). Statistical evaluation also revealed an association between HIF-1 $\alpha$ overexpression and Jaffe grade and recurrence. There were higher HIF- $1 \alpha$ mRNA levels in patients with higher Jaffe grade or recurrence $(\mathrm{P}=0.022$ and 0.009 , respectively). No association was detected between HIF-1 $\alpha$ mRNA expression and any other clinicopathological parameter evaluated.

miR-210 and HIF-1 $\alpha$ are upregulated in primary GCTB stromal cells under hypoxia. To further confirm the correla- 
A

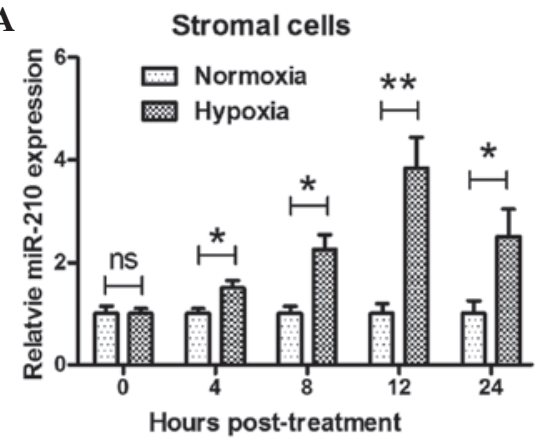

C

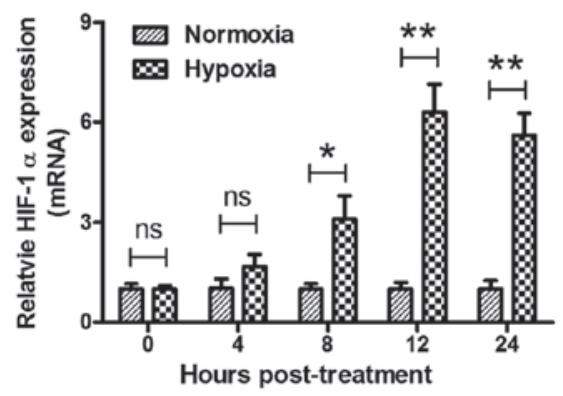

B

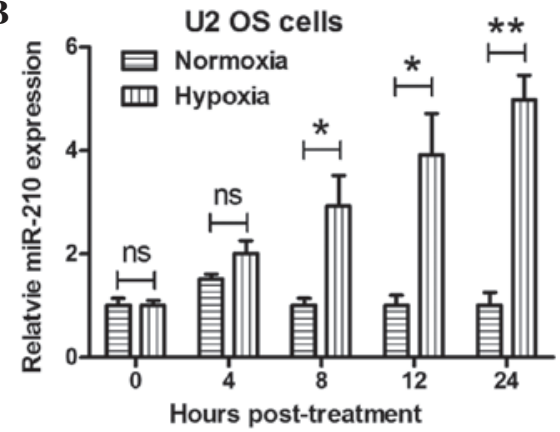

D

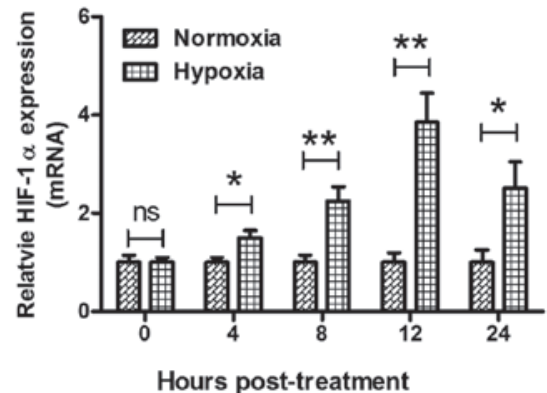

$\mathbf{E}$

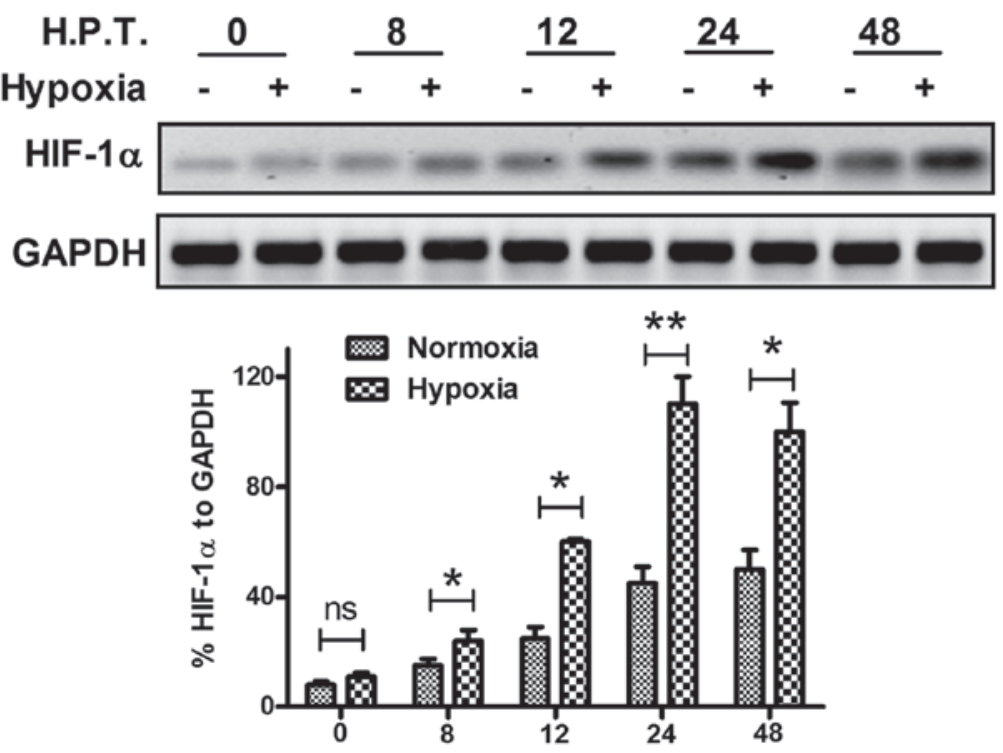

Figure 3. Overexpression of miR-210 and HIF-1 $\alpha$ in primary stromal cells under hypoxia. (A and B) Hypoxia upregulated miR-210 expression in primary stromal and U2 OS human osteosarcoma cells, as determined by RT-qPCR. (C and D) Hypoxia upregulated HIF-1 $\alpha$ mRNA expression in primary stromal and U2 OS cells, as determined by RT-qPCR. (E) Hypoxia upregulated HIF-1 $\alpha$ protein expression levels in primary stromal cells relative to GAPDH, as determined by western blot analysis. All experiments were performed in triplicate. Values are expressed as the mean \pm standard error; ${ }^{*} \mathrm{P}<0.05$, ${ }^{* * *} \mathrm{P}<0.01$. GCTB, giant cell tumor of bone; OS, osteosarcoma; miR-210, microRNA-210; mRNA, messenger RNA; HIF-1 $\alpha$, hypoxia-inducible factor-1 $\alpha$; H.P.T, hours post-treatment.

tion between miR-210 and HIF-1 $\alpha$ expression and hypoxia in GCTBs, primary stromal cells were isolated from GCTB tissues and the miR-210 and HIF-1 $\alpha$ expression levels were examined under hypoxia in the primary stromal and U2 OS human osteosarcoma cells. The miRNA and mRNA samples from the two types of cell under normoxia or hypoxia, were analyzed using RT-qPCR. In agreement with the results of the analysis of the clinical specimens, there was a significant induction of miR-210 expression under hypoxia in the primary stromal and U2 OS cells. The miR-210 expression began increasing from $4 \mathrm{~h}$ post hypoxia treatment, reaching the highest levels at $12 \mathrm{~h}$ post treatment $(\mathrm{P}<0.05$ or $\mathrm{P}<0.01$; Fig. $3 \mathrm{~A}$ and B). Analogous results were observed in the HIF-1 $\alpha$ expression levels in primary stromal and U2 OS cells. Under hypoxic conditions, HIF-1 $\alpha$ expression was significantly upregulated in primary stromal cells from $8-24 \mathrm{~h}$ post treatment, and in U2 OS cells from $4-24$ h post treatment $(\mathrm{P}<0.05$ or $\mathrm{P}<0.01$; Fig. 3C and D). Western blot analysis was utilized to evaluate the upregulation of HIF-1 $\alpha$ protein expression in the primary stromal cells under hypoxia. As shown in Fig. $3 \mathrm{E}$, from 8 to $48 \mathrm{~h}$ post hypoxia treatment, HIF-1 $\alpha$ was significantly upregulated $(\mathrm{P}<0.05$ or $\mathrm{P}<0.01)$. Taken together, these in vitro results confirmed the upregulation in miR-210 and HIF-1 $\alpha$ expression under hypoxia. 

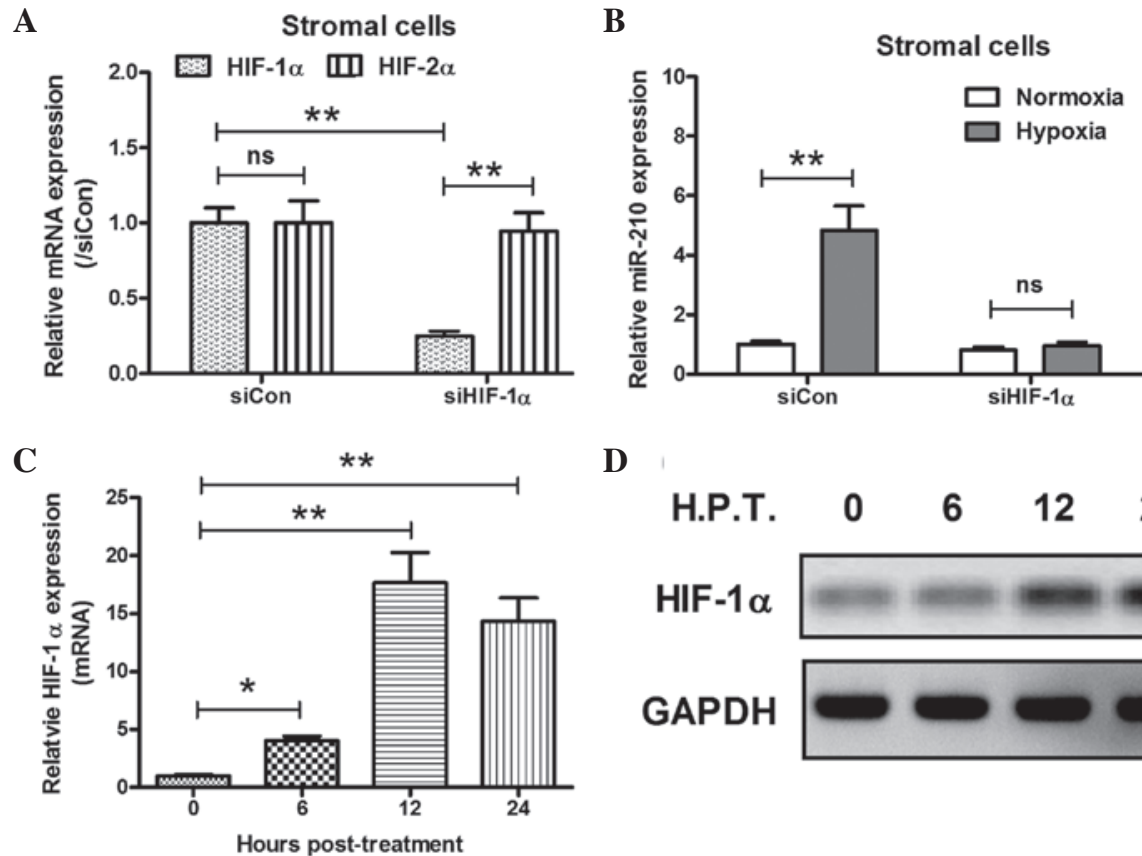

D
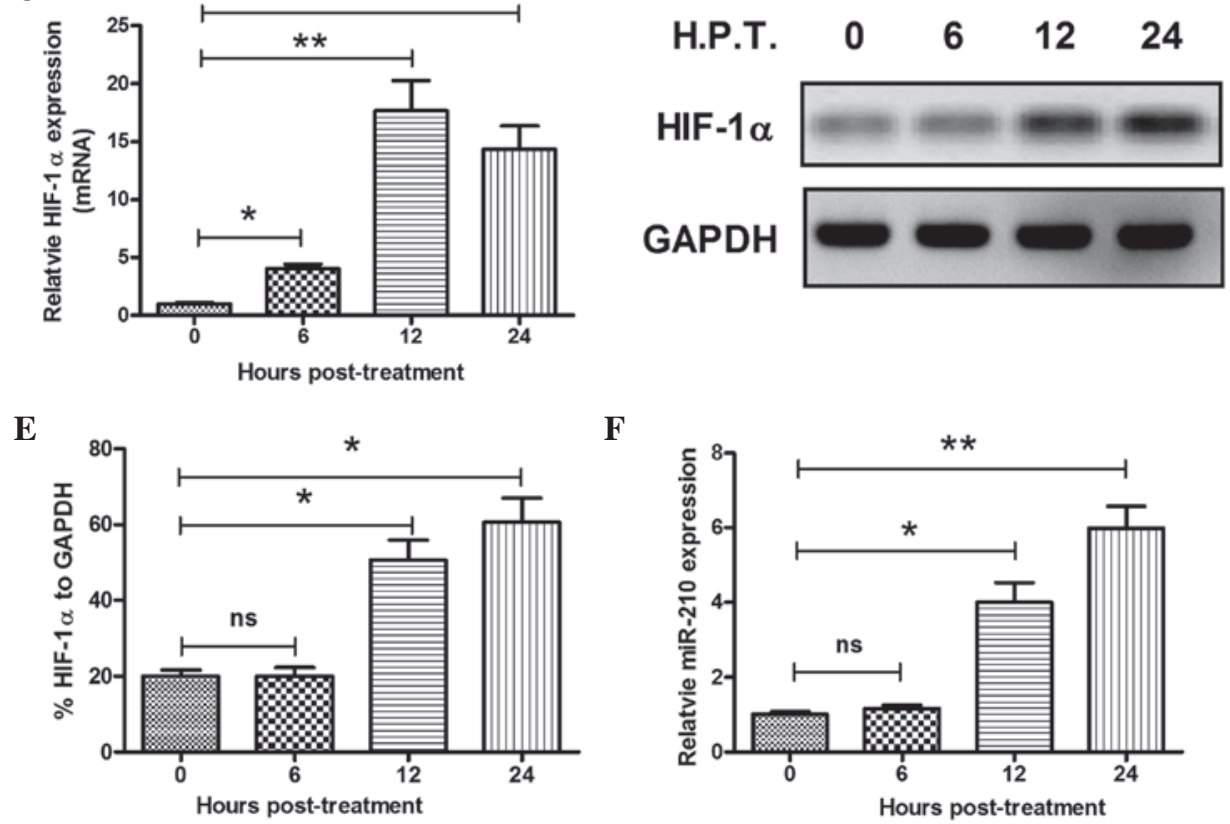

$\mathbf{F}$

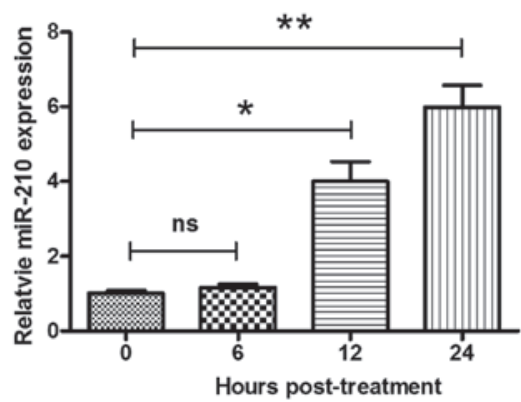

Figure 4. Hypoxia upregulates miR-210 expression in primary stromal cells in an HIF-1 $\alpha$-dependent manner. (A) Reverse transcription-quantitative polymerase chain reaction analysis of HIF-1 $\alpha$ knockdown by HIF-1 $\alpha$ specific siRNA transfection for $24 \mathrm{~h}$ in primary stromal cells. (B) Abrogation of miR-210 induction by hypoxia following HIF-1 $\alpha$ knockdown by transfection of siHIF1 $\alpha$ or siCon for $24 \mathrm{~h}$. Overexpression of HIF-1 $\alpha$ at (C) mRNA level and (D and E) protein level by HIF-1 $\alpha$-pcDNA3.1 transfection for various time-periods $(0,6,12$ and $24 \mathrm{~h}$ ). (F) Upregulation of miR-210 by the overexpression of HIF-1 $\alpha$. All experiments were performed in triplicate. Values are expressed as the mean \pm standard error; ${ }^{*} \mathrm{P}<0.05,{ }^{* *} \mathrm{P}<0.01$. GCTB, giant cell tumor of bone; OS, osteosarcoma; miR-210, microRNA-210; mRNA, messenger RNA; HIF-1 $\alpha$, hypoxia-inducible factor-1 $\alpha$.

Promotion of miR-210 expression in primary GCTB stromal cells by hypoxia is HIF-1 $\alpha$-dependent. In order to explore the correlation between miR-210 expression and the production of HIF-1 $\alpha$, the regulatory effect of HIF-1 $\alpha$ on miR-210 overexpression was determined in primary stromal cells. HIF-1 $\alpha$-specific siRNA was used to block HIF-1 $\alpha$ expression and, as shown in Fig. 4A, siHIF-1 $\alpha$ specifically inhibited HIF-1 $\alpha$ expression, without altering HIF- $2 \alpha$ expression $(\mathrm{P}<0.01)$. Subsequently, miR-210 levels in stromal cells under hypoxic conditions, with or without HIF-1 $\alpha$ blockage by siHIF-1 $\alpha$ were evaluated. Hypoxia promoted miR-210 expression levels to $\sim 5$-fold greater than those under normoxia in primary stromal cells transfected with control siRNA $(\mathrm{P}<0.01)$, while this promotion was blocked by siHIF-1 $\alpha$ (no significant difference compared with the normoxia group; Fig. 4B). To verify that the promotion of miR-210 expression by hypoxia was HIF- $1 \alpha$-dependent, a HIF-1 $\alpha$-pcDNA3.1 recombinant plasmid was constructed and transfected into the primary stromal cells. HIF-1 $\alpha$ expression was significantly upregulated following recombinant plasmid transfection at the mRNA $(\mathrm{P}<0.05$ or $\mathrm{P}<0.01$; Fig. $4 \mathrm{C})$ and protein levels $(\mathrm{P}<0.05$ or $\mathrm{P}<0.01$; Fig. $4 \mathrm{D}$ and $\mathrm{E})$. Furthermore, the high expression of HIF-1 $\alpha$ induced by plasmid transfection significantly enhanced miR-210 expression in the stromal cells, 12 and $24 \mathrm{~h}$ post recombinant plasmid transfection $(\mathrm{P}<0.05$ or $\mathrm{P}<0.01$; Fig. 4F).

\section{Discussion}

The oncogenic or tumor suppressive roles of miRNAs have previously been identified in primary malignant bone tumors, particularly in osteosarcomas (38-43) and Ewing sarcoma cancers $(52,53)$, but not in primary benign bone tumors, including osteomas, osteochondromas and giant cell tumors. Zuntini et al (54) initially identified the deregulated miRNA profiling in multiple osteochondromas, indicating disease-specific miRNA expression in cartilage. A significantly decreased level of miR-136 in metastatic versus non-metastatic GCTBs was also confirmed by RT-qPCR analysis (55). Whether other miRNAs were involved in the GCTBs had remained to be elucidated. In the present study, it was revealed that miR-210 was overexpressed in GCTB specimens, and that this miR-210 overexpression was associated with HIF-1 $\alpha$ overexpression in 
clinical GCTB specimens, as well as primary GCTB stromal cells. Furthermore, the upregulated miR-210 expression in GCTB specimens was correlated with the tumor Jaffe grade and recurrence. Thus, a significant deregulation of miR-210 expression was confirmed in the GCTB stromal cells and specimens, and the miR-210 expression levels may function as a clinical marker for the degree of tumor growth in vivo.

The deregulated growth of solid tumors always involves a hypoxic microenvironment, which drives tumor cells to undergo genetic and phenotypic adaptations that allow them to survive and sustain this deregulated growth under hypoxic conditions. The present study provided evidence indicating that miR-210 was involved in a crucial hypoxia-response network in GCTBs. In order to aid the elucidation of the regulatory networks involved in mediating the hypoxia response, the potential regulators of miR-210 expression were determined, Drosha and Dicer, which are also upregulated under hypoxia. The in vitro results in GCTB stromal cells indicated that HIF-1 $\alpha$ inhibition by siRNA blocked the hypoxia-induced upregulation of miR-210 in primary GCTB stromal cells, while the manipulated overexpression of HIF-1 $\alpha$ significantly enhanced miR-210 expression under normoxia. Therefore, these results revealed that the upregulation of miR-210 induced by hypoxia was HIF-1 $\alpha$-dependent.

Oxygen-dependent regulation of HIF-1 $\alpha$ is dependent on a family of prolyl hydroxylases (PHDs) that hydroxylate HIF-1 $\alpha$ protein at two prolines under normoxic conditions, resulting in the degradation of HIF-1 $\alpha$ (56). Conversely, the expression of PHDs is selectively controlled by HIF-1 and -2 proteins (57). There is a positive feedback loop between the PHDs and HIF-1 $\alpha(58,59)$ under hypoxic conditions. During hypoxia, these prolines are not hydroxylated and therefore HIF-1 $\alpha$ degradation is blocked. It has previously been demonstrated that miR-210 targets glycerol-3-phosphate dehydrogenase 1-like, resulting in the stabilization of HIF-1 $\alpha$ (59). Furthermore, in certain types of cell it has been demonstrated that hypoxia-induced miR-210 is an HIF-1 $\alpha$ target (60), and therefore a positive feedback loop between miR-210 and HIF-1 $\alpha$ has been identified. However, to the best of our knowledge there has been no previous study that has identified the deregulation of miR-210 and HIF-1 $\alpha$ expression in GCTBs, let alone a positive feedback loop between them. The present study demonstrated that the hypoxia-induced miR-210 overexpression in primary GCTB stromal cells was induced by HIF-1 $\alpha$. Whether miR-210 in turn upregulates HIF-1 $\alpha$ under hypoxic conditions in GCTBs remains to be elucidated and requires further investigation.

In conclusion, the overexpression of miR-210 and HIF-1 $\alpha$ was identified in GCTB specimens and primary GCTB stromal cells, and a correlation between the two was observed. The in vitro experiments also indicated that the hypoxia-induced miR-210 upregulation was mediated by HIF-1 $\alpha$. The identified overexpression of miR-210 and HIF- $1 \alpha$ in GCTB specimens in the present study suggests an adaptive response to hypoxia in GCTB, thus implying that hypoxia-associated molecules may be an effective target for treatment of GCTB.

\section{References}

1. Campanacci M, Baldini N, Boriani S and Sudanese A: Giant-cell tumor of bone. J Bone Joint Surg Am 69: 106-114, 1987.
2. Anract P, De Pinieux G, Cottias P, Pouillart P, Forest M and Tomeno B: Malignant giant-cell tumours of bone. Clinico-pathological types and prognosis: a review of 29 cases. Int Orthop 22: 19-26, 1998.

3. Gamberi G, Serra M, Ragazzini P, et al: Identification of markers of possible prognostic value in 57 giant cell tumors of bone. Oncol Rep 10: 351-356, 2003.

4. Miszczyk L, Wydmanski J and Spindel J: Efficacy of radiotherapy for giant cell tumor of bone: given either postoperatively or as sole treatment. Int J Radiat Oncol Biol Phys 49: 1239-1242, 2001.

5. Olivera P, Perez E, Ortega A, et al: Estrogen receptor expression in giant cell tumors of the bone. Hum Pathol 33: 165-169, 2002.

6. Melillo G: Inhibiting hypoxia-inducible factor 1 for cancer therapy. Mol Cancer Res 4: 601-605, 2006.

7. Lin SC, Liao WL, Lee JC and Tsai SJ: Hypoxia-regulated gene network in drug resistance and cancer progression. Exp Biol Med (Maywood) 239: 779-792, 2014.

8. Cummins EP and Taylor CT: Hypoxia-responsive transcription factors. Pflugers Arch 450: 363-371, 2005.

9. Licausi F, Weits DA, Pant BD, Scheible WR, Geigenberger P and van Dongen JT: Hypoxia responsive gene expression is mediated by various subsets of transcription factors and miRNAs that are determined by the actual oxygen availability. New Phytol 190: 442-456, 2011.

10. Semenza GL: Targeting HIF-1 for cancer therapy. Nat Rev Cancer 3: 721-732, 2003.

11. Christofk HR, Vander Heiden MG, Harris MH, et al: The M2 splice isoform of pyruvate kinase is important for cancer metabolism and tumour growth. Nature 452: 230-233, 2008.

12. Wang GL, Jiang BH, Rue EA and Semenza GL: Hypoxia-inducible factor 1 is a basic-helix-loop-helix-PAS heterodimer regulated by cellular $\mathrm{O}_{2}$ tension. Proc Natl Acad Sci USA 92: 5510-5514, 1995.

13. Pouysségur J, Dayan F and Mazure NM: Hypoxia signalling in cancer and approaches to enforce tumour regression. Nature 441: 437-443, 2006.

14. Kaelin WG Jr and Ratcliffe PJ: Oxygen sensing by metazoans: the central role of the HIF hydroxylase pathway. Mol Cell 30: 393-402, 2008.

15. Blancher C, Moore JW, Talks KL, Houlbrook S and Harris AL: Relationship of hypoxia-inducible factor (HIF)-1alpha and HIF-2alpha expression to vascular endothelial growth factor induction and hypoxia survival in human breast cancer cell lines. Cancer Res 60: 7106-7113, 2000

16. Zhong H, De Marzo AM, Laughner E, et al: Overexpression of hypoxia-inducible factor lalpha in common human cancers and their metastases. Cancer Res 59: 5830-5835, 1999.

17. Hanahan D and Folkman J: Patterns and emerging mechanisms of the angiogenic switch during tumorigenesis. Cell 86: 353-364, 1996.

18. Pralhad T, Madhusudan S and Rajendrakumar K: Concept, mechanisms and therapeutics of angiogenesis in cancer and other diseases. J Pharm Pharmacol 55: 1045-1053, 2003.

19. Carmeliet P and Jain RK: Angiogenesis in cancer and other diseases. Nature 407: 249-257, 2000

20. Taylor RM, Kashima TG, Knowles HJ and Athanasou NA: VEGF, FLT3 ligand, PIGF and HGF can substitute for M-CSF to induce human osteoclast formation: implications for giant cell tumour pathobiology. Lab Invest 92: 1398-1406, 2012.

21. Knowles HJ and Athanasou NA: Hypoxia-inducible factor is expressed in giant cell tumour of bone and mediates paracrine effects of hypoxia on monocyte-osteoclast differentiation via induction of VEGF. J Pathol 215: 56-66, 2008.

22. Wülling M, Delling G and Kaiser E: The origin of the neoplastic stromal cell in giant cell tumor of bone. Hum Pathol 34: 983-993, 2003.

23. Morgan T, Atkins GJ, Trivett MK, et al: Molecular profiling of giant cell tumor of bone and the osteoclastic localization of ligand for receptor activator of nuclear factor kappaB. Am J Pathol 167: 117-128, 2005

24. Skubitz KM, Cheng EY, Clohisy DR, Thompson RC and Skubitz AP: Gene expression in giant-cell tumors. J Lab Clin Med 144: 193-200, 2004.

25. Atkins GJ, Haynes DR, Graves SE, et al: Expression of osteoclast differentiation signals by stromal elements of giant cell tumors. J Bone Miner Res 15: 640-649, 2000.

26. Cowan RW, Singh G and Ghert M: PTHrP increases RANKL expression by stromal cells from giant cell tumor of bone. J Orthop Res 30: 877-884, 2012. 
27. Xu M, Song ZG, Xu CX, et al: IL-17A stimulates the progression of giant cell tumors of bone. Clin Cancer Res 19: 4697-4705, 2013.

28. Rao VH, Singh RK, Delimont DC, et al: Transcriptional regulation of MMP-9 expression in stromal cells of human giant cell tumor of bone by tumor necrosis factor-alpha. Int J Oncol 14 291-300, 1999.

29. Kumta SM, Huang L, Cheng YY, Chow LT, Lee KM and Zheng MH: Expression of VEGF and MMP-9 in giant cell tumor of bone and other osteolytic lesions. Life Sci 73: 1427-1436, 2003

30. Kudo N, Ogose A, Ariizumi T, et al: Expression of bone morphogenetic proteins in giant cell tumor of bone. Anticancer Res 29: 2219-2225, 2009.

31. Ambros V: MicroRNA pathways in flies and worms: growth, death, fat, stress and timing. Cell 113: 673-676, 2003.

32. Bartel DP: MicroRNAs: target recognition and regulatory functions. Cell 136: 215-233, 2009.

33. Brennecke J, Hipfner DR, Stark A, Russell RB and Cohen SM: bantam encodes a developmentally regulated microRNA that controls cell proliferation and regulates the proapoptotic gene hid in Drosophila. Cell 113: 25-36, 2003.

34. Reinhart BJ, Slack FJ, Basson M, et al: The 21-nucleotide let-7 RNA regulates developmental timing in Caenorhabditis elegans. Nature 403: 901-906, 2000.

35. Gregory RI and Shiekhattar R: MicroRNA biogenesis and cancer. Cancer Res 65: 3509-3512, 2005.

36. Iorio MV and Croce CM: microRNA involvement in human cancer. Carcinogenesis 33: 1126-1133, 2012.

37. Zhao L, Chen X and Cao Y: New role of microRNA: carcinogenesis and clinical application in cancer. Acta Biochim Biophys Sin (Shanghai) 43: 831-839, 2011.

38. Fan L, Wu Q, Xing X, Wei Y and Shao Z: MicroRNA-145 targets vascular endothelial growth factor and inhibits invasion and metastasis of osteosarcoma cells. Acta Biochim Biophys Sin (Shanghai) 44: 407-414, 2012.

39. Duan Z, Choy E, Harmon D, et al: MicroRNA-199a-3p is downregulated in human osteosarcoma and regulates cell proliferation and migration. Mol Cancer Ther 10: 1337-1345,

40. Pan Z, Sun X, Shan H, et al: MicroRNA-101 inhibited postinfarct cardiac fibrosis and improved left ventricular compliance via the FBJ osteosarcoma oncogene/transforming growth factor-beta1 pathway. Circulation 126: 840-850, 2012.

41. Yuan J, Chen L, Chen X, Sun W and Zhou X: Identification of serum microRNA-21 as a biomarker for chemosensitivity and prognosis in human osteosarcoma. J Int Med Res 40: 2090-2097, 2012.

42. van der Deen M, Taipaleenmaki H, Zhang Y, et al: MicroRNA-34c inversely couples the biological functions of the runt-related transcription factor RUNX2 and the tumor suppressor p53 in osteosarcoma. J Biol Chem 288: 21307-21319, 2013.

43. Mao JH, Zhou RP, Peng AF, et al: microRNA-195 suppresses osteosarcoma cell invasion and migration in vitro by targeting FASN. Oncol Lett 4: 1125-1129, 2012

44. Fasanaro P, Greco S, Lorenzi M, et al: An integrated approach for experimental target identification of hypoxia-induced miR-210. J Biol Chem 284: 35134-35143, 2009.
45. Mizuno Y, Tokuzawa Y, Ninomiya Y, et al: miR-210 promotes osteoblastic differentiation through inhibition of AcvR1b. Febs Lett 583: 2263-2268, 2009.

46. Ramakrishnan A, Torok-Storb B and Pillai MM: Primary marrow-derived stromal cells: isolation and manipulation. Methods Mol Biol 1035: 75-101, 2013.

47. Wang XH, Zhao FJ, Han BM, et al: Primary stromal cells isolated from human various histological/pathological prostate have different phenotypes and tumor promotion role. Chin Med J (Engl) 124: 1700-1707, 2011.

48. Zhao JH, Luo Y, Jiang YG, He DL and Wu CT: Knockdown of $\beta$-Catenin through shRNA cause a reversal of EMT and metastatic phenotypes induced by HIF-1 $\alpha$. Cancer Invest 29: 377-382, 2011.

49. Livak KJ and Schmittgen TD: Analysis of relative gene expression data using real-time quantitative PCR and the 2(-Delta Delta C(T)) method. Methods 25: 402-408, 2001.

50. Mutharasan RK, Nagpal V, Ichikawa $Y$ and Ardehali H: microRNA-210 is upregulated in hypoxic cardiomyocytes through Akt- and p53-dependent pathways and exerts cytoprotective effects. Am J Physiol Heart Circ Physiol 301: H1519-H1530, 2011.

51. Biswas S, Roy S, Banerjee J, et al: Hypoxia inducible microRNA 210 attenuates keratinocyte proliferation and impairs closure in a murine model of ischemic wounds. Proc Natl Acad Sci USA 107: 6976-6981, 2010.

52. Riggi N, Suvà ML, De Vito $\mathrm{C}$, et al: EWS-FLI-1 modulates miRNA145 and SOX2 expression to initiate mesenchymal stem cell reprogramming toward Ewing sarcoma cancer stem cells. Genes Dev 24: 916-932, 2010.

53. Ban J, Jug G, Mestdagh P, et al: Hsa-mir-145 is the top EWS-FLI1-repressed microRNA involved in a positive feedback loop in Ewing's sarcoma. Oncogene 30: 2173-2180, 2011.

54. Zuntini M, Salvatore M, Pedrini E, et al: MicroRNA profiling of multiple osteochondromas: identification of disease-specific and normal cartilage signatures. Clin Genet 78: 507-516, 2010.

55. Mosakhani N, Pazzaglia L, Benassi MS, et al: MicroRNA expression profiles in metastatic and non-metastatic giant cell tumor of bone. Histol Histopathol 28: 671-678, 2013.

56. Vogel S, Wottawa M, Farhat K, et al: Prolyl hydroxylase domain (PHD) 2 affects cell migration and F-actin formation via RhoA/rho-associated kinase-dependent cofilin phosphorylation. J Biol Chem 285: 33756-33763, 2010.

57. Fujita N, Markova D, Anderson DG, et al: Expression of prolyl hydroxylases (PHDs) is selectively controlled by HIF-1 and HIF-2 proteins in nucleus pulposus cells of the intervertebral disc: distinct roles of PHD2 and PHD3 proteins in controlling HIF-1alpha activity in hypoxia. J Biol Chem 287: 16975-16986, 2012.

58. Demidenko ZN and Blagosklonny MV: The purpose of the HIF-1/PHD feedback loop: to limit mTOR-induced HIF-1alpha. Cell Cycle 10: 1557-1562,2011.

59. Kelly TJ,Souza AL,Clish CB andPuigserverP: Ahypoxia-induced positive feedback loop promotes hypoxia-inducible factor 1alpha stability through miR-210 suppression of glycerol-3-phosphate dehydrogenase 1-like. Mol Cell Biol 31: 2696-2706, 2011.

60. Krock BL, Skuli N and Simon MC: Hypoxia-induced angiogenesis: good and evil. Genes Cancer 2: 1117-1133, 2011. 